\title{
The impact of backyard gardening on livelihoods of households in Sedibeng District Municipality in Gauteng Province, South Africa
}

Thomas M.M. ${ }^{1}$ and Terblanche, S.E ${ }^{2}$

Corresponding author: M.M Thomas. Email: maureen.thomas@gauteng.gov.za

\begin{abstract}
The study was conducted to evaluate the impact of backyard gardening on the livelihoods of households in Sedibeng District Municipality in Gauteng Province, South Africa. Data were drawn from 60 household vegetable producers. A structured questionnaire was used to conduct one-on-one interviews to gather data which were then analysed to compare variables and the level of livelihoods of household vegetable production. The results suggested that variables such as gender, household size, marital status and household income influence vegetable production. Women, as the primary caretakers of children, were found to be more involved in vegetable production than men. The vegetable production increased when households were headed by females. Households indicated that the implementation and evaluation of the programme under study, which was successfully undertaken with the assistance of Agricultural Advisors from Gauteng's Department of Agriculture and Rural Development (GDARD), did impact their livelihoods positively. In conclusion, the study found that household vegetable projects can assist in alleviating poverty, create job opportunities and improve livelihoods of the community of Sedibeng District Municipality.
\end{abstract}

Keywords: Gardening, self-efficacy, smallholder farmers

\section{INTRODUCTION}

The present study was conducted to evaluate the impact of backyard gardening on the livelihoods of households in Sedibeng District Municipality in Gauteng Province, South Africa. This research was undertaken recognising that the growing global human population, which is anticipated to double by 2050, has driven the need for an increased supply of food to cater for the nutritional needs of people; hence the need to develop, food security (UNPD, 2008; FAO, 2009). Because a greater part of the projected population increase is expected to take place in developing countries, backyard and schoolyard gardening have a significant role to play in bridging the worldwide malnutrition deficiency gap. Over time, it has come to be recognised that growing vegetables, which are predominantly freshly produced, is the fastest means of bridging the malnutrition deficiency gap due to their short growing period (IFAD, 2014).

\footnotetext{
1 Agricultural Advisor, Gauteng Department Of Agriculture And Rural Development, 77 Strydom Street, Birchleigh North, Kempton Park 1618, Email Address: Maureen.Thomas@ Gauteng.Gov.Za

2 Senior Lecturer, Department of Agricultural Economics, Extension and Rural Development, University of Pretoria, Pretoria 0002, Tel. 012-4204623; Fax: 012-4203247; E-mail: fanie.terblanche@up.ac.za.
} 
Furthermore, vegetable gardening contributes towards food security, poverty alleviation, enhanced livelihood and the creation of employment for rural communities (Antwi \& Seahlodi 2011). However, in South Africa, the recent drought, declining grain production and increasing human population have compelled households to devise alternative means of producing food in a manner other than commercial farming. In addition, IFAD (2014) in its' report, projected that the world would experience an increase in extreme weather conditions, which will have a negative impact on agricultural activities. These challenges would lead to a rise in food prices which would compromise the livelihoods of rural households (Turpie \& Visser, 2013). This is a terrifying scenario, especially regarding household food security.

The Sedibeng District community engages in different activities so that its' members can earn their living. The involvement of disadvantaged South African communities in agricultural activities is due to persistent poverty, resulting in people engaging in cheap labour to improve their income (Sibanda, 2001). These communities rely on a combination of livelihood strategies, such as social grants, agricultural projects and cheap labour (Nell, Maine \& Basson, 2006). Therefore, it is critical to understand the perceptions of households concerning backyard and school gardening. Backyard and school gardening are vital interventions for improving nutrition and food security for deprived rural households. In addition, 'policy interventions for agricultural activities have demonstrated a great track record of accomplishment of reduction of poverty, greater economic growth and improving livelihoods of the communities' (Turner et al., 2013).

In Gauteng Province, millions of people are residing in poor peri-urban areas and agriculture has proven to have a great potential to alleviate poverty in a short space of time for these communities. Communities who want to transform their livelihoods through agriculture projects are demotivated due to lack of resources for agricultural production. The Gauteng Department of Agriculture and Rural Development (GDARD) and the national Department of Agriculture Land Reform and Rural Development (DALRRD) have established a support service programmes to improve agricultural production and promote economic development through adequate financial support, infrastructure, marketing and capacity building (Jordaan \& Jooste, 2003) for peri-urban communities. In addressing the post-settlement support and poverty levels in the country, DALRRD initiated the Comprehensive Agriculture Support Programme (CASP) in order to support the agricultural industry to handle the situation of increasing poverty in South Africa and the programme was launched in August 2004 (DOA, 2004). The programme initiated and developed six key development preferences as a way of intervention. These comprised: Knowledge management and information; Advisory and technical assistance; Provision of services on a regular basis; Capacity building and training; Development of business and markets on and off farm infrastructure; and Financial assistance for farmers. The present study was therefore conducted to evaluate the impact of backyard gardening on livelihoods of household in Sedibeng district municipality of Gauteng Province, South Africa. 


\section{METHODOLOGY}

\subsection{Description of the study area}

The study was conducted in Sedibeng District Municipality (SDM), Gauteng Province, South Africa; the area was selected based on its' agricultural farming activities and use of water for agricultural purposes as well as its demographic structures (income bracket, employment status, level of education, marital status, age and gender). The main languages spoken in Sedibeng District Municipality are IsiZulu (21\%), Afrikaans (14\%), Sesotho (13\%) and English (12\%).

The SDM is regarded as a Category $\mathrm{C}$ municipality in Gauteng Province The district forms part of the maize triangle' and the main agricultural practices in the municipality are agronomic crops (e.g. maize rotated with sunflowers). The municipality is located at the southern tip of Gauteng and consists of three district municipalities: Emfuleni, Lesedi and Midvaal (Figure 1). The SDM borders Johannesburg Metropolitan Municipality; Delmas Local Municipality; Ekurhuleni Metropolitan Municipality; and Merafong and Metsimaholo local municipalities. The Sedibeng District Municipality has a total geographical area of 5,185 square kilometres $\left(\mathrm{km}^{2}\right)$ land cover, of which Midvaal Local Municipality covers over 1,728 $\mathrm{km}^{2}$, followed by Lesedi accounting for $1,489 \mathrm{~km}^{2}$ and Emfuleni, which covers $1,968 \mathrm{~km}^{2}$. The total population of Sedibeng is in the region of 916484 people, of which Lesedi Local Municipality has an estimated population of 99520 people, Midvaal Local Municipality has 95301 people, while the estimated population of Emfuleni Local Municipality is 721663 people (IDP 2019/2020).

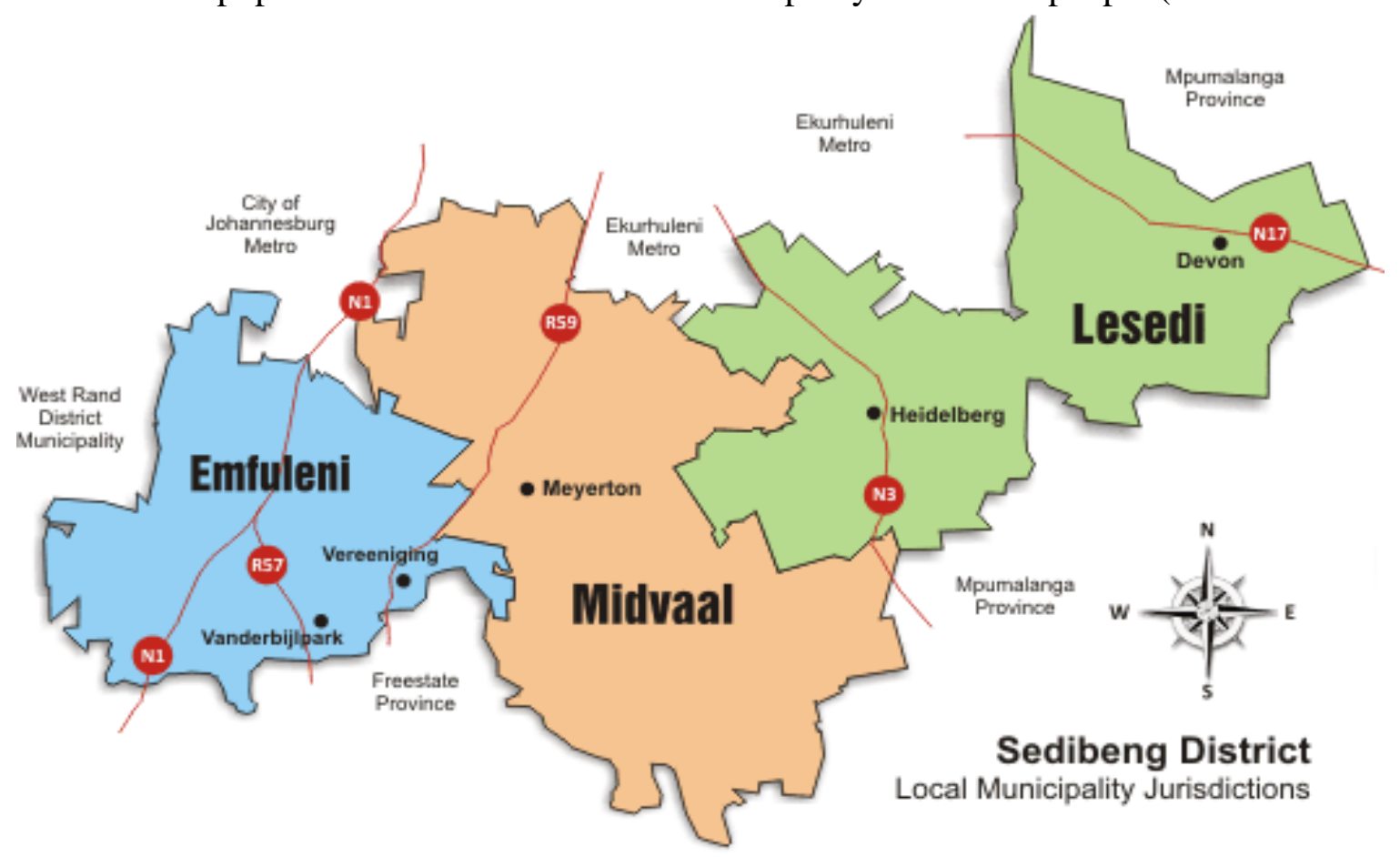

Figure 1 Map of Sedibeng District Municipality (Source: IDP 2019/2020) 


\subsection{Conceptual Framework}

The conceptual framework adopted in this study is built on the relationship between backyard gardening and an improvement in farm household. The production decision of a household is affected by internal and external factors. The internal factors are the household characteristics such as age, education level and household size as well as farming experience, income level and gender, while the external factors are the institutional factors such as transaction costs, extension services and land tenure. The production decision will include what to produce, how much to produce and how to produce, all of which is constrained by the amount of inputs that are available as well as the size of the available land.

\subsection{Data Collection and Analysis}

The data were collected using a structured questionnaire from sixty (60) vegetable producing households in Sedibeng District Municipality. Van Niekerk, (2002) suggested that to measure the beliefs, values, attitudes, norms and type of information held by individuals, the investigator may use a questionnaire survey method. A structured questionnaire was used to conduct oneon-one interviews was used for collecting data. This method permitted the interviewer to observe the behaviour of the respondents, which the questionnaire was not designed to detect. A questionnaire was developed in English and during the interviews the questions were translated into IsiZulu and Sesotho (Babbie, 2001). Translation reduced any misunderstanding of certain words or the incorrect interpretation of questions by respondents, who were illiterate. The data were analysed using descriptive statistics: percentages, frequency distribution, averages/mean, and mode scores (Gerber-Nel et al., 2005). A version 20.0 for Windows, Statistical Package for Social Sciences (SPSS) was used to analyse data. Thereafter, graphs and tables were used to illustrate results of the study.

\subsection{Ethical Considerations}

Ethical considerations were followed during the data collection process. Ethical accountability towards the respondents was maintained to ensure no one was harmed in any possible way. The study avoided using inquisitive questions and embarrassing questions as research instruments. All the participants were notified that they could abstain from responding to questions that they felt uncomfortable about answering. In addition, respondents were informed that, they can walk away anytime they felt uncomfortable with the interview.

\section{RESULTS AND DISCUSSION}

Distribution of the respondents in Sedibeng District by gender revealed that the females accounted for about $70 \%$ of the population and males accounted for $30 \%$ of the population. Challenges, such as limited or no information, technological challenges, production inputs and 
access to markets are barriers that prevent female farmers from performing at optimum level. Women are the principal carers of children, meaning that they have limited time and mobility to undertake all farming activities and they tend to be less educated than men. Women play a very important role in the communities and in the household activities. However, the agricultural sector largely depends upon the role women play in order for the sector to succeed. Helm (2005) and Matela (2002), reported that women provided almost $70 \%$ of the agricultural labour force in Africa, the results of which the current study is in agreement with. In addition, results showed that $61 \%$ of married adults were in the majority (Figure 2); this could possibly be attributed to their being eager to earn, due to the need to provide for their families. Mihiteru (2008) indicated that when it comes to the use and adoption of technology, women and men are likely to play different roles due to socio-cultural norms and values. In most cases, males participate in extension programmes (at different levels) and have freedom of mobility and consequently, it is suggested that males have greater access to information.

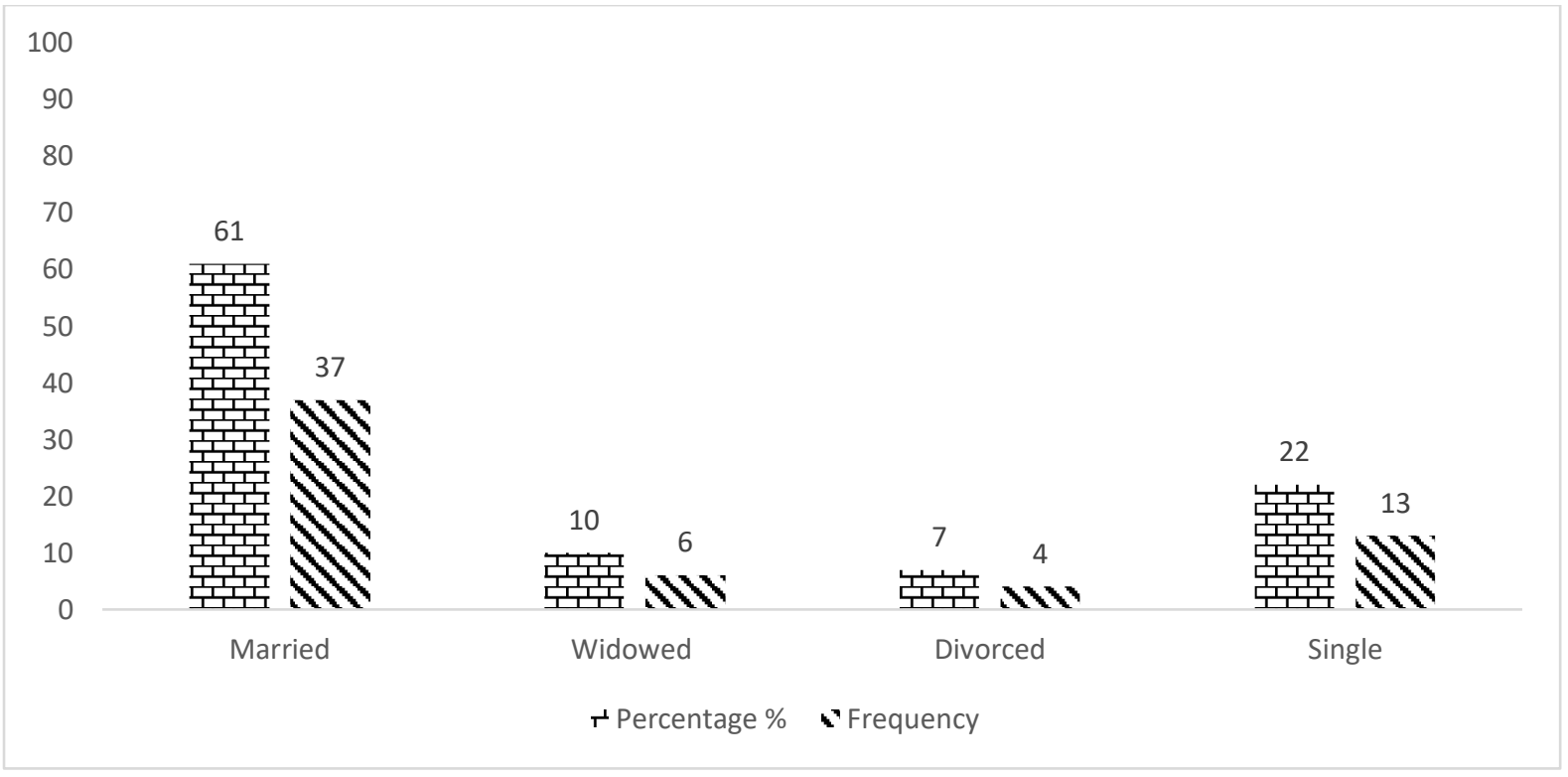

\section{Figure 2 Marital status of participants}

In Table 1, below, records that the majority of the respondents were 55 years and above (older); there was a mean age of 36 years and the minimum age was 18 years. Respondents who were 55 years and above, constituted 68 percent of the participants; the respondents below 34 years of age made up 7 percent of the participants, which was lower than the number of respondents between the ages of 35-54 years (25 percent). This suggests that older people in Sedibeng District are involved in back yard gardening activities. The explanation could be that younger people migrate to urban areas to search for job opportunities with higher incomes or, that young people are not interested in agricultural activities, possibly due to the perception that employment in the agricultural sector has a lower income. In addition, the explanation could be that older people are the ones responsible for feeding the household. However, Dejere (2006) reported that farmers who are creative are capable of earning a high income. In addition, 
Van Rooyen \& Njobe-Mbule, (1996) reported that farmers who are 45 years and older are most likely to succeed in agricultural enterprises; a position with which the current study concurs.

Table 1 Age Distribution of the farmers who were interviewed $(n=60)$

\begin{tabular}{|l|l|l|l|}
\hline Age & Variables description & Frequency & Percentage $(\%)$ \\
\hline $18-34$ & 4 & 4 & 7 \\
\hline $35-54$ & 15 & 15 & 25 \\
\hline 55 and above & 41 & 41 & 68 \\
\hline
\end{tabular}

The level of formal education was assumed to be a determinant of increasing agricultural production. Hoag et al. (1999) reported that a respondent's level of education often positively influences adoption of technology. The level of education translated to good management, good financial management and the use of modern technologies, such as the use of hybrid seeds. In addition, Sebadieta et al. (2007) reported that education allowed the farmer to explore different ways of obtaining agricultural information, technology and processing the information. Bester et al. (1999) reported that in developing countries, literacy is one of the limiting factors to achieving physical, social, economic and technical education. Therefore, adoption of new technologies by farmers is influenced by educational consideration (Bester et al., 1999).

As indicated in Table 2, it was observed that $62 \%$ of the respondents had high school certificates, $27 \%$ had University qualifications and $7 \%$ had just primary schooling. However, just $23 \%$ of the respondents had an agricultural qualification. The table also reveals that while $63 \%$ were employed, $37 \%$ were unemployed. In support of these findings, Bembridge (2000) argues that adoption of new technologies may be influenced by lack of knowledge. This was in agreement with the findings as the majority of farmers had primary to secondary education level. In addition, Ziervogel et al. (2006) reported that the ability to process information means the farmer can adopt and apply new technology that can be of benefit to themselves and the overall production.

The size of the family was considered to be the number of individuals who reside with the head of the household. The results of the current study showed that family size ranged between 5 and 11 people per household. This may imply that households had enough labour to produce their own vegetables farmed by people living within the households. The average number of people per household was 6, which was similar to findings in a report by Paddy (2003). In addition, Hayes et al. (1997) suggested that a bigger household implied the household with different generation intervals (young to older people) had labour force (Hayes et al., 1997). This was consistent with the results of the current study, which found that households were made up of $70 \%$ of adults; $23.3 \%$ of youth, while the children comprised the remaining $7 \%$.

Farm production and income were factors affecting household decisions concerning participation in back yard agricultural projects. This appeared to be due to the nature of 
employment which a head-of-household is able to generate income from agricultural projects. The majority of the participants' responses indicated that they were farming as a group $(65 \%)$ compared to those who were farming individually (35\%).

Table 2 Frequency of education level, employment and experience of the farmers interviewed

\begin{tabular}{|l|l|l|l|}
\hline Variables & Variables description & Frequency & Percentage (\%) \\
\hline Education Level & Not educated & 0 & 0 \\
\hline & Primary & 7 & 11 \\
\hline & High School/Secondary & 37 & 62 \\
\hline & University/ College/FET? & 16 & 27 \\
\hline Number of people & Adults & 306 & 70 \\
\hline & Youth & 132 & 30 \\
\hline Agric. Qualification & Yes & 16 & 27 \\
\hline & No & 44 & 73 \\
\hline Years' Experience & $<5$ Years & 15 & 25 \\
\hline & 20 Years plus & 17 & 75 \\
\hline Land Size (ha) & $<2$ & 7 & 12 \\
\hline & $3-5$ & 25 & 42 \\
\hline & $6-10$ & 17 & 28 \\
\hline & $11-20$ & 8 & 13 \\
\hline & 21 plus & 3 & 5 \\
\hline
\end{tabular}

However, as illustrated in (Figure 3, below) findings indicated that the purpose of backyard gardening was to create employment opportunities (76.7\%), earn income (15\%) and improve the livelihood of the community $(8.3 \%)$. The households indicated that they produced different commodities, and this was informed by environmental factors and areas where the respondents were residing. In addition, markets and demand for certain commodities drove the type of products produced by the households. 


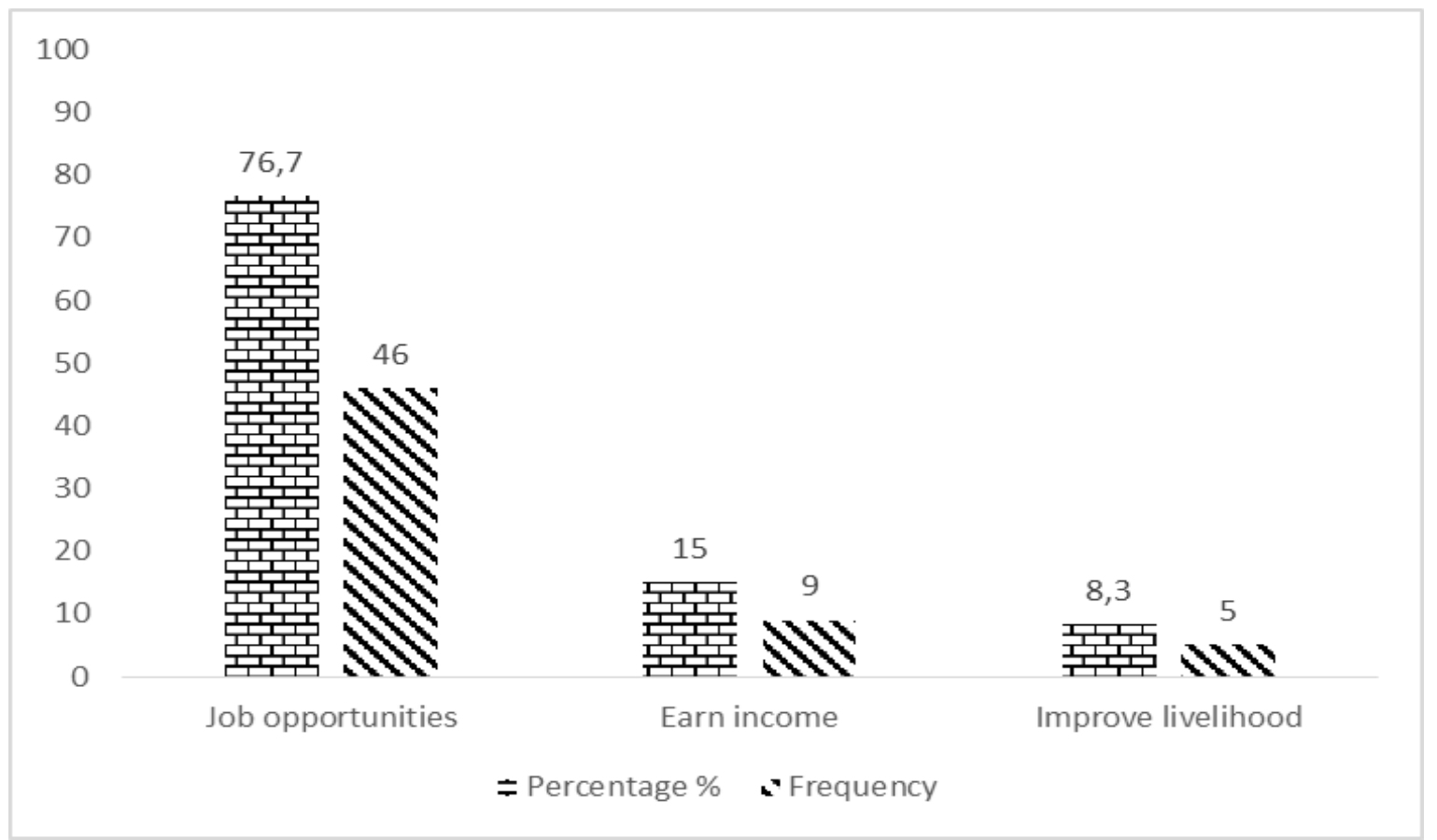

Figure 3 Purpose of household vegetable production

Figure 4 , below, indicates that $62 \%$ of the respondents are producing spinach, $15 \%$ cabbage, $10 \%$ tomato, $8 \%$ potatoes, $3 \%$ onion and $2 \%$ were producing other commodities.

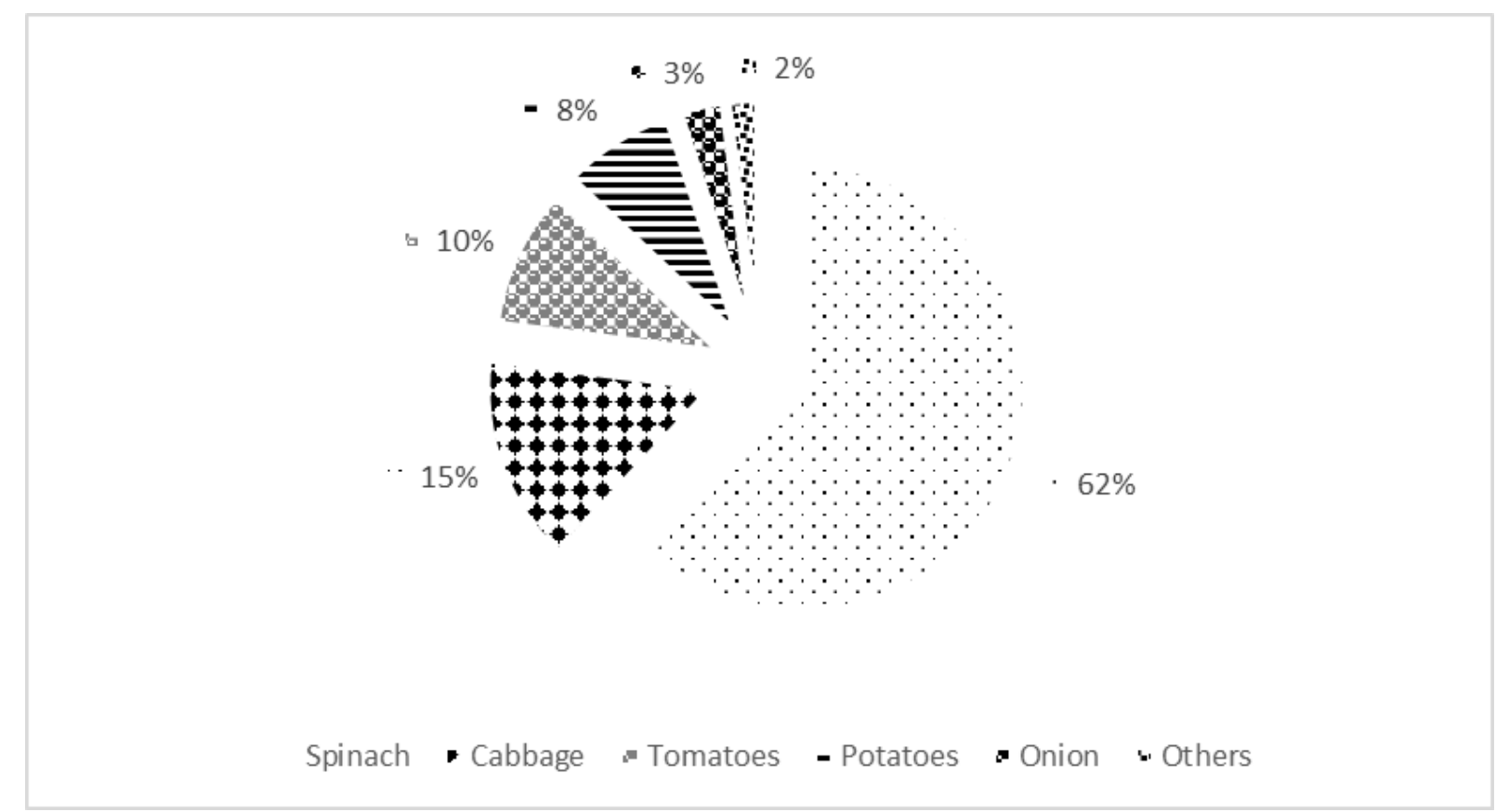

Figure 4 Type of vegetable produced

Bembridge (2000) reported that money received by backyard vegetable producers in South Africa, from sales of vegetables accounts for $10 \%$ of income. As recorded in Table 3, below, the respondents indicated that $53.3 \%$ of them had business plans and $46.7 \%$ did not have 
business plans. In addition, $81.7 \%$ had access to a market and $18.3 \%$ did not have market access. Of these, $33 \%$ were selling at the formal market, $20 \%$ were selling at informal markets and $47 \%$ were selling at both formal and informal markets. Households were engaged in different types of market arrangements: $55 \%$ had written contracts; $13.3 \%$ had verbal contracts and $31.7 \%$ had both written and verbal contracts. All the respondents $(100 \%)$ indicated that they had support from GDARD Agricultural Advisors to market their produce.

Table 3 Type of markets and contracts for the farmers interviewed (n60)

\begin{tabular}{|l|l|l|l|}
\hline Variables & Variables description & Frequency & Percentage (\%) \\
\hline Business plan & Yes & 32 & 53.3 \\
\cline { 2 - 4 } & No & 28 & 46.7 \\
\hline Market access & Yes & 49 & 81.7 \\
\cline { 2 - 4 } & No & 11 & 18.3 \\
\hline \multirow{5}{*}{ Type of market } & Formal market & 20 & 33 \\
\cline { 2 - 4 } & Informal market & 12 & 20 \\
\cline { 2 - 4 } & Both & 28 & 47 \\
\hline Type of contract & Verbal contract & 8 & 13.3 \\
\cline { 2 - 4 } & Written contract & 33 & 55 \\
\cline { 2 - 4 } & Both & 19 & 31.7 \\
\hline \multirow{3}{*}{ Support to market } & Yes & 60 & - \\
\cline { 2 - 4 } & No & - & 100 \\
\hline
\end{tabular}

The backyard gardeners interviewed indicated their farm income as shown in Table 4. The respondents indicated that, per annum, 30\% were generating between R201, 000-300,000; 25\% between R301, 000-400,000 and 10\% between R401, 000-500,000. However, 12\% and 18\% of the respondents were making an income of between R101 $000-200000$ and less than R100 000 respectively. Just 5\% were generating more than R500000.

Table 4 Total farm income per annum

\begin{tabular}{|l|l|l|l|}
\hline Variables & Variables description $(\mathrm{R})$ & Frequency & Percentage (\%) \\
\hline Farm income & $<100000$ & 7 & 12 \\
\hline & $101000-200000$ & 11 & 18 \\
\hline & $201000-300000$ & 18 & 30 \\
\hline & $301000-400000$ & 15 & 25 \\
\hline & $401000-500000$ & 6 & 10 \\
\hline & $<500000$ & 3 & 5 \\
\hline
\end{tabular}

The size of the household plays a significant role in the perception of agriculture. The main activity driving the economy for the women and youth in the study area, was found to be agricultural production, due to poverty and high levels of unemployment.

\section{CONCLUSION}


Backyard gardening was prominent for the community of Sedibeng district municipality and some households were seasonal gardeners, while some did very little gardening because of water challenges. Farmers faced various production and marketing constraints, but the major constraints were lack of water, low quality materials supplied, lack of market, lack of storage facilities, lack of market facilities and poor prices. Government should have a comprehensive value chain for backyard gardens so as to avoid some of the production and marketing challenges that the farmers are facing. As for the lack of water constraint, it is important that another source of water be identified and used instead of relying on rainfall. Unreliable rainfall and insufficient water for crop production is a major constraint to improving the welfare of households as it results in low productivity. Based on lack of market, many households are selling their produce locally. Gross margin analysis of the different garden crops revealed that gardening activity is viable. The economic impact of the backyard garden in terms of consumption expenditure of households was higher for beneficiaries indicating a positive impact of the backyard garden programme towards their incomes. Hence it was concluded that the backyard garden programme plays a crucial role in improving the livelihoods of the community of Sedibeng district municipality as it has the potential to increase household income.

\section{ACKNOWLEDGEMENTS}

The author wishes to acknowledge the Gauteng Department of Agriculture and Rural Development (GDARD) and all managers who enabled us to use the facilities and departmental resources. A special thanks to the backyard vegetable farmers who participated in the research study.

\section{REFERENCES}

ANTWI, M. \& SEAHLODI, P. 2011. Marketing constraints facing emerging small-scale pig farmers in Gauteng province, South Africa, J. Hum. Ecol., 36, 37-42

BEMBRIDGE, T.J. 2000. Guidelines for Rehabilitation of Small-Scale Farmer Irrigation Schemes in South Africa, WRC Report No 891/1/00, Water Research Commission, ISBN 1- 86845-683-8, Gezina, South Africa

BESTER, B. J., BELETE, A. \& DONI, T. M. 1999. An application of probit analysis to factors affecting small-scale farmers' decision to participate in the Farmer Support Programme: A case study in the Eastern Cape province of South Africa. Agrekon, 38(1) 
DEJERE, H. 2006. Assessment of farmers' evaluation criteria and adoption of improved bread wheat varieties in Akaki, Central Ethiopia. MSc. Presented to the School of Graduate Studies of Alemeya University

FOOD AND AGRICULTURE ORGANISATION (FAO). 2009. 'FAO's Director-general on how to feed the world in 2050', Population and Development Review, 35: 837-839

HAYES, J., ROTH, M. \& ZAPEDA, L. 1997. Tenure security, investment and productivity in Gambian agriculture: A generalized profit analysis. American Journal of Agricultural Economics, 79(2): 369-378

HELM, C. 2005. Precision farming in South Africa. Farm Technology Proceedings, 76-80

HOAG, D.L., ASCOUGH I.J.C. \& FRASIER, W.M. 1999. Farm computer adoption in the Great Plains. Journal of Agricultural and Applied Economics, 31, 57-67

INTERNATIONAL FUND FOR AGRICULTURAL DEVELOPMENT (IFAD). 2014. The adaptation advantage: The economic benefits of preparing small-scale farmers for climate change. Available from: https://www.ifad.org/documents/10180/0a24e2483f96-49af-b2df-ebbce284335c

JORDAAN, A. J. \& JOOSTE, A. 2003. Strategies for the support of successful land reform: A case study of QwaQwa emerging commercial farmers. S.Afri.J.Agric.Ext./ S.Afri.Tydskr. Landbouvoorl., 32

PADDY, F. 2003. Gender differentials in land ownership and their impact on household food security: A case study of Masaka district. Master's Thesis, Uganda. Press, Baltimore and London. [Online] Available from: http://www.troz.unihohenheim.de/research/Thesis/MScAES/Paddy.pdf

MATELA, N. 2002. The status of precision agriculture in South Africa. Unpublished MSc dissertation. University of the Free State, Bloemfontein, South Africa

NELL, W. T., MAINE, N. \& BASSON, P. M. 2006. Africa. In Handbook of precision agriculture. Srinivasan (Ed.). The Haworth Press, Inc

SIBANDA, S. 2001. Land reform and poverty alleviation in South Africa. Paper presented at the SARPN Conference on Land Reform and Poverty Alleviation in Southern Africa, held at the Human Science Research Council, Pretoria. Pp.5 
TURNER, R., HAWKES, C., WAAGE, J., FERGUSON, E., HASEEN, F., \& HOMAN, H. 2013. Agriculture for improved nutrition: The current research landscape. Food Nutr. Bull. 2013; 34 369-377

TURPIE, J. \& VISSER, M. 2013. Chapter 4: The impact of climate change on South Africa's rural areas. Available from: file:///C:/Users/user/AppData/Local/Packages/Microsoft.MicrosoftEdge_8wekyb3d8b bwe/TempState/Downloads/Chapter_4_Impact_of_climate_change_on_South_Africa s_rural_areas $2 \% 20(1) . p d f$

VAN ROOYEN, J. \& NJOBE- MBULE, B. 1996. Access to land, selecting the beneficiaries. Oxford University Press

ZIERVOGEL, G., NYONG, A., OSMAN, B., CONDE, C., CORTES, S. \& DOWNING, T., 2006. Climate variability and change: Implications for household food security. AIACC Working Paper No. 2 